\title{
For Quality Education Money is not the Only Thing That Matters
}

Arthur Horton*

Professor, Lewis University, One University Parkway Drive Romeoville, IL, USA

*Corresponding author: Arthur Horton, Professor, Lewis University, One University Parkway Drive Romeoville, IL, USA, Tel: 8158365314; E-mail: ahorton756@aol.com Received date: May 06, 2016; Accepted date: May 12, 2016; Published date: May 19, 2016

Copyright: (c) 2016 Horton A. This is an open-access article distributed under the terms of the Creative Commons Attribution License, which permits unrestricted use, distribution, and reproduction in any medium, provided the original author and source are credited.

\begin{abstract}
Mr. Duncan, Head of the Department of Education, said the estimate, based on an analysis of testing trends and the workings of the federal law's pass-fail school rating system, was the latest evidence of the law's shortcomings and the need to overhaul it. Even many of the nation's best-run schools are likely to fall short of the law's rapidly rising standardized testing targets, Mr. Duncan said. "This law is fundamentally broken, and we need to fix it this year," he told the House education committee (New Y Mr. Duncan, Head of the Department of Education, said the estimate, based on an analysis of testing trends and the workings of the federal law's pass-fail school rating system, was the latest evidence of the law's shortcomings and the need to overhaul it. Even many of the nation's best-run schools are likely to fall short of the law's rapidly rising standardized testing targets, Mr. Duncan said. "This law is fundamentally broken, and we need to fix it this year," he told the House education committee (New York Times, March10, 2011, pg.A16).

The Common Core is a stateled effort that is not part of No Child Left Behind or any other federal initiative. The federal government played no role in the development of the Common Core. State adoption of the standards is in no way mandatory. States began the work to create clear, consistent standards before the American Recovery and Reinvestment Act, which provided funding for the Race to the Top grant program. It also began before the Elementary and Secondary Education Act blueprint was released, because this work is being driven by the needs of the states, not the federal government. This study examines the impact of teachers and principals on student outcome.
\end{abstract}

Keywords: Quality; Education; Money

\section{For Quality Education Money is not the Only Thing That Matters}

On February 17, 2009, President Obama signed into law the American Recovery and Reinvestment Act of 2009 (ARRA), historic legislation designed to stimulate the economy, support job creation, and invest in critical sectors, including education. The ARRA lays the foundation for education reform by supporting investments in innovative strategies that are most likely to lead to improved results for students, long-term gains in school and school system capacity, and increased productivity and effectiveness.

The ARRA provides $\$ 4.35$ billion for the Race to the Top Fund, a competitive grant program designed to encourage and reward States that are creating the conditions for education innovation and reform; achieving significant improvement in student outcomes, including making substantial gains in student achievement, closing achievement gaps, improving high school graduation rates, and ensuring student preparation for success in college and careers; and implementing ambitious plans in four core education reform areas:

Adopting standards and assessments that prepare students to succeed in college and the workplace and to compete in the global economy.

Building data systems that measure student growth and success, and inform teachers and principals about how they can improve instruction.
Recruiting, developing, rewarding, and retaining effective teachers and principals, especially where they are needed most; and Turning around our lowest-achieving schools.

Race to the Top will reward States that have demonstrated success in raising student achievement and have the best plans to accelerate their reforms in the future. These States will offer models for others to follow and will spread the best reform ideas across their States, and across the country. The specific section of interest is cited below:

\section{Overview of Program and Points}

D. Great Teachers and Leaders (138 points)

1. Providing high-quality pathways for aspiring teachers and principals (21 points)

2. Improving teacher and principal effectiveness based on performance (58 points)

3. Ensuring equitable distribution of effective teachers and principals (25 points)

4. Improving the effectiveness of teacher and principal preparation programs (14 points)

5. Providing effective support to teachers and principals (20 points)

E. Turning Around the Lowest-Achieving Schools (50 points)

1. Intervening in the lowest-achieving schools and LEAs (10 points)

2. Turning around the lowest- achieving schools (40 points)

This paper provides a study of the correlations of rewards, at least, salaries and student performance, i.e., standardized test results. For 
teachers at the high school and elementary levels do high salaries reduce the low performance of students, i.e., for school districts with high numbers of underachieving schools? The results of the research conducted in this study challenges some of the assumptions of the current administration's education reform policies [1,2]. Do the years of experience, as a variable, have any positive impact on low performing schools? Is it possible that monetary reward or any valuation of academic effectiveness operationalized in strict financial terms distorts educational processes? Effective teachers don't become educators for the money although it is appropriate to be compensated for the labor involved as a skilled teacher, is that a possibility? However, many aspects of teaching as a service are done for no charge. I quote from the Chicago Sun-Times Newspaper (Sun-Times, May31, 2011) "We're not just teachers," says Chicago's Dirksen Middle School teacher Crystal Pedroni. We're nurses, counselors; we are their parents when their parents are not there."

Even the cost of a person's total education in preparation for professional teaching is not appropriately determined in the standard salary. At the higher education level alone there is considerable variance in tuition in Harvard college of Education, the University of Illinois at Chicago and where I am a faculty in social work, but we have a college of Education. We should not ignore the works of Jonathan Kozol that identifies the funding extreme funding variance by school district for K-12 education across the nation. This is important if were to factor in early schooling in the total cost to become a teacher. Public education in this country utilizes an approach of leveling in entry of teachers in the occupation of teacher for grades K-12. For many school districts teacher certification adds to no premium in salary negotiations. Another way to look at this is it true that you must compensate accordingly to get the best and brightest teachers? However some school districts do offer elaborate benefits. In one school district in Illinois, More than half the high school teachers earn $\$ 100,000$ or more a year even though more the exception than the rule. There is the frequent justification that higher average salary may be driven by the fact that in one district, for example, teachers have master's degrees and several have double -masters. At any rate school districts with highly paid teacher typically are located in affluent communities with relatively high property taxes with as much quite often as $70 \%$ of that going to the school district. In Illinois, 11.25 percent of high school teachers and 2.26 percent of elementary-grade teachers were at $\$ 100,000$ or better. Statewide, the average elementary made \$ 61,140-including all benefits, summer school pay, after school stipends and retirement payouts. The average high teacher took home $\$ 69,366$.

At the other side of the correlation is the percent of students meeting or exceeding state standards. In the city of Chicago where the typical teacher stands in front of a classroom comprised of $87 \%$ lowincome kids, teacher salaries are relative low. Results from the 2009 National Assessment of Education Progress, commonly called the Nation's Report Card, showed Chicago's eight graders scored 27 points lower (out of 300 total) than their peers nationwide in their understanding of several core areas of science; physical, life, earth and space. Chicago's fourth graders fared slightly better scoring 24 points lower than students nationally. Though Cities such as New York City, Atlanta, Boston, Miami and Houston ranked ahead of Chicago, the overall findings showed a widening achievement gap between urban and suburban districts that is of concern to the Obama administration.
More than half of District113 full-time teachers received at least \$ 100,000 in total compensation, including benefits and extra pay for extracurricular activities.

For this study data were obtained for all school district in the state of Illinois. Data are utilized for both high and elementary teachers. Data are utilized for both high school and elementary principals. In this instance, average is one of the variables that includes, base, summer, after -school pay, benefits, vacation or sick-day payouts preretirements salary bumps The average includes only full-time employees working at least nine months a year. The source of the data is the Illinois State Board of Education. The state board all so provides data pertaining to percent of low income students by school district, the years of experience for teachers at the elementary and high school levels by school districts, and most importantly the percent of students at/or exceeding standards (high school and elementary) levels by school district.

\section{Methodology}

For this study there are four major hypotheses as follows:

1. The percent of students that exceed/meet standards is directly related to teacher salaries and years of experience, but inversely related to percent of low- income students. The sample is the 25 lowest paying school districts.

2. The percent of students that exceed/meet standards is directly related to teacher salaries and years of experience, but inversely related to the percent of low -income students.

3. The sample is the highest 25 highest paying school districts.

4. The percent of students that exceed/meet standards is directly related to principal salaries and years of experience and inversely related to the percent of low-income students. The sample is the 25 highest paying school districts

5. The percent of students that exceed/meet standards is directly related to principal salaries and years of experience and inversely related to the percent of low-income students. The sample is the 21 lowest paying school districts.

In four of the 25 lowest paying districts there were missing data.

The variables are as follows: $c 4=$ exceeds/or equals standards; $c 2=$ years of experience; $c 3=\%$ low -income; and c5 = salaries.

The study uses linear regression for multiple variables with equations stated as follows:

1. $\quad c 4=c 5+c 2-c 3$ where $c 4=92.9-0.00014 c 5+0.276 c 2-0.337 c 3$ This can be represented as a Table 1 .

\begin{tabular}{|l|l|l|l|l|l|}
\hline \multirow{2}{*}{ Predictor } & & $\begin{array}{l}\text { Coefficie } \\
\text { nt }\end{array}$ & St. dev. & T-ratio & $\mathbf{P}$ \\
\cline { 2 - 6 } & & 90.49 & & 13.16 & \\
\hline c5 & & & $5 \mathrm{E}-05$ & 0.0004 & 0.12 \\
\hline $\mathrm{c3}$ & & & 0.341 & 0.0559 & -6.1 \\
\hline $\mathrm{c} 2$ & & & 0.304 & 0.3351 & 0.91 \\
\hline R-square $=48.2 \%$ & $\begin{array}{l}\text { R-square (adj.) } \\
=44.9 \%\end{array}$ & & & & \\
\hline
\end{tabular}


Citation: Horton A (2016) For Quality Education Money is not the Only Thing That Matters. Clin Exp Psychol 2: 125. doi:

Page 3 of 7

\begin{tabular}{|l|l|l|l|l|}
\hline F-statistic $=14.59$ & & & & \\
and p value = & & & & \\
0.000 & & & & \\
\hline
\end{tabular}

2. $c 4=c 5+c 2-c 3$ where $c 4=90.2+0.0000001 c 5+0.442 c 2-$ $0.349 \mathrm{c} 3$

This can be represented as a Table 2 .

Table 1: Lowest paying school districts (elementary teachers) OLS estimates.

\begin{tabular}{|l|l|l|l|l|l|l|l|}
\hline \multirow{2}{*}{ Predictor } & Coefficient & St.dev. & T-ratio & & P & & \\
\cline { 2 - 8 } & 90.182 & & 7.632 & & 11.82 & \\
\hline c5 & & $1 \mathrm{E}-07$ & & 0.0001 & 0.01 & 0 \\
\hline c3 & & -0.349 & & 0.0278 & -12.55 & 0 & \\
\hline c2 & & 0.4416 & & 0.2815 & 1.57 & \\
\hline $\begin{array}{l}\text { R-square }=89.1 \% \text { and R-square (adj.) } \\
87.6 \%\end{array}$ & & & & & & \\
\hline F-statistic $=57.28$ and $p$ value $=0.0000$ & & & & & & & \\
\hline
\end{tabular}

Table 2: Highest paying school districts (elementary teachers) OLS estimates.

3. $c 4=c 5+c 2-c 3$ where $c 4=13.0+0.000437 c 5+1.89 c 2-0.541 c 3$

This can be represented as a Table 3 .

\begin{tabular}{|c|c|c|c|c|c|c|c|c|c|}
\hline \multirow{2}{*}{ Predictor } & Coefficient & & St. dev. & T-ratio & & $\mathbf{P}$ & & & \\
\hline & 12.95 & & & 42.07 & & 0.31 & & 0.761 & \\
\hline c5 & & 0.0004 & & 0.0004 & 1.02 & & 0.319 & & \\
\hline c3 & & -0.541 & & 0.1755 & 3.08 & & 0.006 & & \\
\hline $\mathrm{c} 2$ & & 1.895 & & & 2.04 & & 0.93 & & 0.36 \\
\hline \multicolumn{10}{|l|}{$\begin{array}{l}\text { R-square }=40.6 \% \quad R \text { - } \\
\text { square(adj.) }=32.1 \%\end{array}$} \\
\hline $\begin{array}{l}\text { F-statistic }=4.78 \text { and } p \text { value } \\
0.011\end{array}$ & & & & & & & & & \\
\hline
\end{tabular}

Table 3: Highest paying school districts (high school teachers) OLS estimates.

4. $c 4=c 5+c 2-c 3$ where $c 4=36.2+0.000220 c 5+1.60 c 2-0.304 c 3$

This can be represented as a Table 4 .

\begin{tabular}{|l|l|l|l|l|l|l|l|}
\hline \multirow{2}{*}{ Predictor } & $\begin{array}{l}\text { Coeffici } \\
\text { ent }\end{array}$ & & $\begin{array}{l}\text { St. } \\
\text { dev. }\end{array}$ & $\begin{array}{l}\text { t- } \\
\text { rati } \\
\text { o }\end{array}$ & & p & \\
\cline { 2 - 8 } & & 36.3 & & & 28.47 & & 1.27 \\
\hline c5 & & & 0.0002 & & 0.0006 & 0.38 & \\
\hline c3 & & -0.304 & & 0.1787 & -1.7 & \\
\hline c2 & & & 1.603 & & & 1.092 & \\
\hline $\begin{array}{l}\text { R-square = 29\% R- } \\
\text { square(adj.) =16.5\% }\end{array}$ & & & & & & & \\
\hline
\end{tabular}

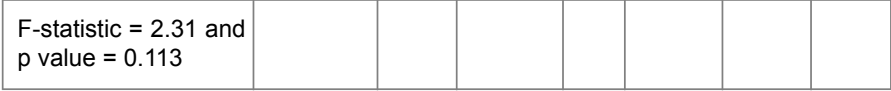

Table 4: Lowest paying school districts (high school teachers) OLS estimates.

As a secondary aspect of this study I consider the impact of the salaries of principals. The hypotheses are as follows:

1. The percent of students that exceed/meet standards is directly related to the salaries and the years of experience of high school principals and is inversely related to the percent of low-income students. Salaries and years of experience are averages for schools districts.The data for the variables are only for the top ten highest paid high school principals in the state of Illinois.

2. The percent of students that exceed/meet standards is directly related to the salaries and the years of experience of elementary school principals and inversely related to the percent low income of students by school district. Salaries and years of experience are 
the averages for a given school district. The data for the variables are only for the top ten highest paid elementary principals in the state of Illinois.
Thus, $c 4=86.7-0.0000022 \mathrm{p} 1+0.137 \mathrm{p} 2-0.713 \mathrm{c} 3$

This can be represented as a Table 5 .

The regression equations are as follows:

$\mathrm{c} 4=\mathrm{p} 1+\mathrm{p} 2-\mathrm{c} 3$ where $\mathrm{c} 4=$ exceeds/meets standards; $\mathrm{c} 3=$ percent of low-income students; $\mathrm{p} 1=$ average salaries(high school principals); and $\mathrm{p} 2=$ average years of experience(high school principals).

\begin{tabular}{|c|c|c|c|c|c|c|c|c|}
\hline \multirow{2}{*}{ Predictor } & coefficient & & st.dev & t-ratio & & $\mathbf{p}$ & & \\
\hline & 86.68 & & & 29.48 & & 2.94 & & 0.026 \\
\hline c3 & & -0.713 & & 0.1515 & -4.7 & & 0.003 & \\
\hline $\mathrm{p} 1$ & & $-2 \mathrm{E}-05$ & & 0.0001 & -0.17 & & 0.869 & \\
\hline p2 & & 0.1372 & & 0.0659 & 0.21 & & 0.842 & \\
\hline $\begin{array}{l}\text { R-square }=82.4 \% \\
\text { (adj.)73.6\% }\end{array}$ & & & & & & & & \\
\hline F-statistic $=9.38$ and $p$ value $=0.01$ & & & & & & & & \\
\hline
\end{tabular}

Table 5: Highest paid high school principals (estimates).

1. $\quad c 4=p 1+p 2-c 3$ which same as above except elementary teacher pertains for average salaries (P1) and average years of experience $(\mathrm{p} 2)$.
Thus, $c 4=129-0.0478 \mathrm{p} 2-0.327 \mathrm{c} 3-0.0002063 \mathrm{p} 2$

This can be represented as a Table 6 .

\begin{tabular}{|c|c|c|c|c|c|c|c|}
\hline \multirow{2}{*}{ Predictor } & coefficient & & st.dev. & t-ratio & & $\mathbf{p}$ & \\
\hline & 128.82 & & 10.46 & & 12.33 & & 0 \\
\hline c3 & & -0.033 & & 0.0153 & -21.3 & 0 & \\
\hline p1 & & $-2 \mathrm{E}-04$ & 7E-05 & -2.84 & & 0.03 & \\
\hline p2 & & -0.048 & & 0.5994 & -0.8 & & 0.455 \\
\hline $\begin{array}{l}\text { R-square }=\quad 99.1 \% \\
\text { square( adj.) }=98.7 \%\end{array}$ & & & & & & & \\
\hline $\begin{array}{l}\text { F-statistic }=221.12 \text { and } \quad p \\
\text { value }=0.000\end{array}$ & & & & & & & \\
\hline
\end{tabular}

Table 6: Highest paid elementary principals (estimates).

\section{Discussion and Analysis}

At this juncture we exam the finding and start with the results indicated in Table 1. The constant term is useful here because it is statically significant and indicates that the slope for the parameters of best fit in the regression model. Apparently, there are identified factors that directly (positively versus inversely) related to the dependent variable (testing results). Of the specified independent variables only the variable or indicator of the number of low-income students is statistically significant.

Nevertheless, close to $50 \%$ of the coefficient of determination is reflected in the selection of the specified variables. At any rate, the relatively insignificant contribution of the variables teacher salaries and years of experience (elementary grades) has to be considered. Again, these findings pertain to the 25 lowest paying school districts in terms of average salaries. Next we examine the findings for the 25 highest paying school districts.
As we see in Table 2 the constant terms is statistically significant and twice the value as reflected in Table 1 . The coefficient for the constant term is positive. But if you consider the coefficient of determination it is about $90 \%$ this indicates that only $10 \%$ of the explanatory variables are yet not specified. Even with teacher receiving higher salaries that variable is not statistically significant and is unlikely to change much with the addition of more independent variables. In the second model, despite salaries being at higher levels (ranging for the top 10 from an average of $\$ 84,864$ per school district to $\$ 71,161$ - City of Chicago and much more than the statewide average of $\$ 6144$ ) the impact is not there regarding low-income students. To the contrary not only is the variable representing the number of low-income students inversely related ,i.e., as the while controlling for salaries increase in the second model that variable as has twice the value for statistical (-12.55 vs. 6.10). Let us see if this pattern persists for the high school level. 
What we see at the high school level in Table 3 the variable representing the number of low-income students is inversely related to the dependent variable as before not at same strength but statistically significant. The salaries of the highestpaid principals has while controlling for the number of low income has neglible impact on state test of student learning. For the lowest salary per school district as presented in Table 4 the impact of the number of low- income students has diminished considerably to the effect of not being statistically significant. However, please observe that teacher salaries and years of experience have neglible impact while controlling for the number of low-income students. It should be observed that the years experience as a factor in all four models is not statistically significant. Going back to the discussion of the constant term please observe that from model one to model four it decreases in importance as the coefficients and also in statistical significance. However, this speculative and warrant further research but I hypothesize a school dropout factor. The effect could be as follows.

There is difference of the effect for affluent school districts as opposed to marginalized poorly funded school districts. The affluent districts in Tables 2 and 3 by high years are challenged by high school drop rates for minority students who are disproprotionately represented in the low-income student category in such school districts This helps to reduce the low-income student impact at the high school level (from roughly (-12 to-3 in terms of statistical significance). For the school districts with lowest paid teachers these districts will a relative large number of low-income students (from $50 \%$ to 90\%) In some of these districts race and ethnicity may influence the drop- out rate by the high school grade levels. In general testing results could be improved and it seems to be feasible in the context of the findings in Tables 1 and 4 . However, there is still the possible effect of poor student retention by the end of the high schools years.

There are other results of this study that need to be addressed. As indicated in Tables 5 and 6 there are the findings pertaining to the highest paid teachers and principals in the State of Illinois. The sample in both instances is only the top 10 of the average salaries by school district. The controlling variables are again specified in the respective models. At the high school level principal salaries had no statistical while controlling for the variable, the number of low-income students. The latter, however, is, once again, statistically significant. At the elementary level, the variable highest average teacher salary is statistically significant yet the variable, years of experience, is not. The key point is that the variable, the number of low-income students, is inversely related and at relative high level of statistical significance. Please observe that the coefficient of determination is at $99 \%$ with only $1 \%$ of the explanation of the variation in the dependent variable not being explained by the specified variable. If the desired effect increasing principal salaries (monetary rewards) to increase student learning for low-income category of students the evidence is not there. In fact, based on the correlations as the average salaries for the top ten school districts increase the percent of students meeting or exceeding standards decreases, which is statistically significant that is while controlling for the percent of low-income students.

At this juncture, I shift the focus and examine various aspects of public policy and what's at stake. I start with crisis in public education and then go more long term.

Mr. Duncan, Head of the Department of Education, said the estimate, based on an analysis of testing trends and the workings of the federal law's pass-fail school rating system, was the latest evidence of the law's shortcomings and the need to overhaul it. Even many of the nation's best-run schools are likely to fall short of the law's rapidly rising standardized testing targets, Mr. Duncan said. "This law is fundamentally broken, and we need to fix it this year," he told the House education committee (New York Times, March10, 2011, pg.A16).

Eighty-two percent of schools could miss testing targets, Mr. Duncan said, compared with 37 percent last year. Some analysts who have closely followed the workings of the law expressed skepticism about the estimates.

No Child Left Behind Act, introduced in 2001 by President George W. Bush and passed by Congress with bipartisan support, requires that all schools bring 100 percent of their students to proficiency in math and reading by 2014. Mr. Duncan has called this requirement "utopian." Critics of the law say it is a bit like requiring all city police forces to end certain crimes - like burglary and drug trafficking - by 2014. They have also long predicted that the law will, over time, determine that all but a handful of schools are failing - a label that would demoralize educators, lower property values and mislead parents about the instructional climates in their schools.

President Obama, Mr. Duncan and many Republicans would like Congress to rewrite the testing and other much-criticized provisions of the law in a broad overhaul this year. The sprawling federal law requires all public schools to conduct annual testing of reading and math skills among students in third through eighth grades and one high school grade. They must publish the average results for all students, as well as the results broken down by ethnic groups and other subsets.

When it took effect in 2002, the law required states to outline the 12-year statistical path they would follow in bringing all students to proficiency by 2014.California, for example, had only 14 percent of its students proficient in reading in 2002, but it promised to raise that level in every school by a few points each year. The state vowed to have 35 percent of students proficient by 2008, 57 percent by 2010 and 100 percent by 2014. But like most other states, California has had trouble keeping up. By 2009, 39 percent of the state's elementary schools had missed the targets; last year, 60 percent of California's elementary schools fell short.

If students in any ethnic group miss the targets, the entire school is put on probation. Schools that miss targets two years in a row are labeled "needing improvement," and face escalating sanctions that can include staff changes or shutdowns. In virtually every state, schools designated as needing improvement include chaotic ones that may need a total overhaul but also many others where only one or two groups' scores - perhaps the results of disabled students - have fallen short.

The Obama administration's blueprint for rewriting the law, released last year, would retain many features of the Bush-era law, including its annual testing requirements. But it proposes far-reaching changes, including replacing the pass-fail school accountability system with one that would measure individual students' academic growth and judge schools on other indicators like graduation rates, not just test scores. The administration's proposal would replace the 2014 goal with a new national target, raising standards so that all students who graduated from high school by 2020 were prepared to succeed in college and a career.

As I indicated previously, not only must we address the immediate crisis in public education for the elementary and high school years, we 
Page 6 of 7

must think of empowering America's youth in the long-term and preparing them for future challenges [3]. The model that I propose is presented below. It incorporates my own ideas and aspects an initiative underway in the state of Illinois. Due to the nature of this paper it is given in broad and generic form. Many of the details must be supplied with input and assistance of educators, parents, community leaders and those with the appropriate technological expertise/resources shown in Figures 1, 2 and 3.

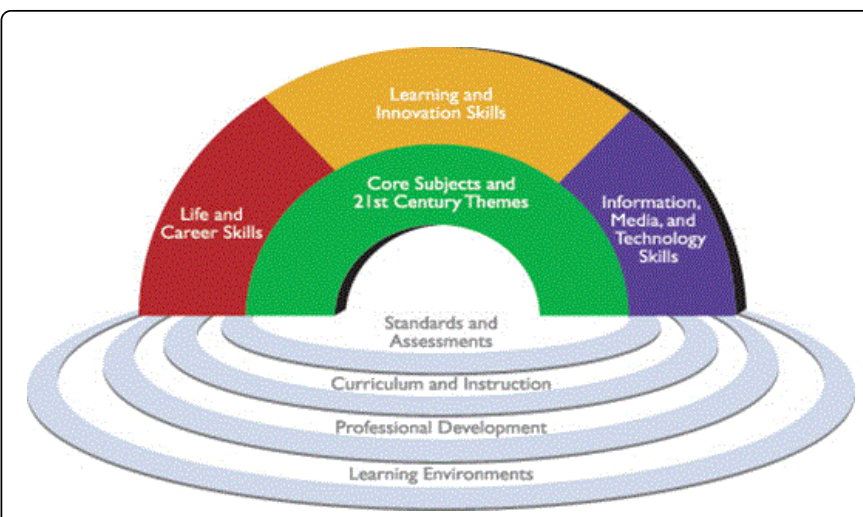

Figure 1: Core subjects and 21st century themes.

\section{Teaching \& Learning in $21^{\text {st }}$ Century:}

\section{Outcomes}

\begin{tabular}{|c|c|}
\hline Students can & Teacherscan \\
\hline $\begin{array}{l}\text { - Engage in exciting ways with } \\
\text { dynamic, real-time content not found } \\
\text { in textbooks. } \\
\text { - Access resource without waiting for } \\
\text { "computer time." } \\
\text { - Become self-directed leamers with } \\
\text { improved analytical and } \\
\text { communication skills. } \\
\text { - Master multimedia presentation } \\
\text { skills and software, preparing them for } \\
\text { workforce success. } \\
\text { - Carry their learning environments } \\
\text { wit h them for flexible research and } \\
\text { communication with teachers. }\end{array}$ & $\begin{array}{l}\text { - Customize the learning process and } \\
\text { paceto fit individual styles and } \\
\text { abilitiest. } \\
\text { - Refine their own practices, tactically } \\
\text { and strategicallyt. } \\
\text { - Give students information-gathering } \\
\text { resources, freeing time from lecturing } \\
\text { and enabling teachers-as-consultants. } \\
\text { - Create learning environments un- } \\
\text { tet hered to desks and classrooms. } \\
\text { - Collaborate more easily with peers } \\
\text { and parents, and enable inter-school } \\
\text { partnerships. }\end{array}$ \\
\hline
\end{tabular}

Figure 2: Teaching and learning in $21^{\text {st }}$ century outcomes.

The No Child Left Behind Left Act, the 2001 legislation that reauthorized the Elementary Secondary Education Act (ESEA), ushered in an era that prioritized high-sto the single measure of performance on these tests. According to the National Center of Fair and Open Testing which has voiced and open critique of the growing reliance on standardized test, youth of color are disproportionately affected by grade retention( being held back) as a result of this practice. Performances on national standardized testing twelfth--grade Black girls is 273 , which is lower than all other groups of girls taking the test. See the U.S. Department of Education, Institute of Education Sciences, National Assessment of Education Progress (NAEP), 1992, 1994, 1998, 2002, 2005, 2009 and 2013. These controversial, single measures of knowledge may deter Black girls from continuing on with their education or lead to them to internalize that they are not worthy of completing school, when their performance may actually be impaired by many other factors, including socio-economic conditions, differential learning styles, the quality of instruction at their schools, the orientation and presentations of questions on the test, their own mental and physical health and disparities in access to early childhood education.

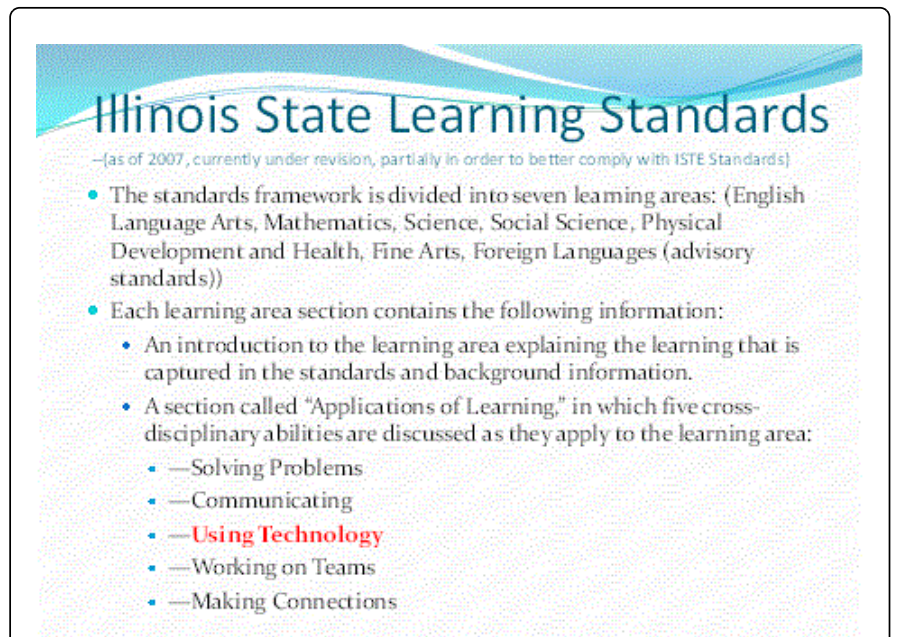

Figure 3: Illinois state learning standards.

Based on the findings of the study there is evidence that challenges the assumption of the current administration regarding the effectiveness of monetary incentives to reduce the poor test results of low- income students [3-5]. Studies addressing peer- group effects explore the idea that a child's social ties in school influence his or her individual learning [6]. These studies consistently find that having a higher proportion of ethnic minority or low-income students in a school is correlated with lower levels of individual student achievement. However, such peer group effects may be expressions of culture of poverty dynamics if child and family risk factors accumulate at the schooling level due to residential segregation. Again, Jonathan Kozol has documented this in his work regarding "apartheid education" in this country. From a social justice perspective, we note that even cultural processes" may ultimately reflect structural causes to the degree that an individual's choices, beliefs values and behaviors are shaped by unequal access to resources and opportunities, institutional oppression, and processes of marginalization. One such structural cause is the quality of education itself [7].

\section{References}

1. American Psychological Association (2006) Evidenced-based practices in psychology. American Psychologist 61: 271-285.

2. Gambrill E (2006) Evidence-based practice and policy: Choices ahead. Research on Social Work Practice 16: 338-357.

3. Garcia E, Arias MB, Harris-Murri NJ, Sema C (2011) Developing responsive teachers: A challenge for a demographic reality. Journal of Teacher Education 61: 132-142.

4. Valencia SE, Martin SD, Place NA, Grossman P (2009) The Social Structures of student teacher education (2009). Journal of Teacher Education 60: 394-302.

5. Yogen E, Michaeli N (2011) Teachers as society- involved organic "intellectuals": Training teachers in a political context. Journal of Teacher Education 62: 312-324. 
Citation: Horton A (2016) For Quality Education Money is not the Only Thing That Matters. Clin Exp Psychol 2: 125. doi: 10.4172/2471-2701.1000125

Page 7 of 7

6. Bankston JR, Caldas SJ (1998) Family structure, schoolmates, and racial inequalities in school achievement. Journal of Marriage and the Family 60: $715-723$.
7. Fram MS, Miller-Cribbs JE, Horn LV (2007) Poverty, race and the context of achievement: Examining educational experiences of children in the U.S. south. Soc Work 52: 309-319. 